\title{
PROFILE OF CONSUMPTION OF PSYCHOACTIVE SUBSTANCES AND ITS RELATIONSHIP TO SOCIODEMOGRAPHIC CHARACTERISTICS: A CONTRIBUTION TO A BRIEF INTERVENTION IN PRIMARY HEALTH CARE, RIO DE JANEIRO, BRAZIL ${ }^{1}$
}

\author{
Angela Maria Mendes Abreu², Pedro Miguel Santos Dinis Parreira3, Maria Helena do Nascimento Souza4, \\ Teresa Maria Mendes Diniz de Andrade Barroso 5
}

\footnotetext{
${ }^{1}$ This study was supported by the Ministry of Health and the Ministry of Education through the National Program for Reorientation of Professional Training in Health (PRO PET-Saúde/Saúde da Família) and CNPq for the development of a post-doctorate program abroad at the Nursing School of Coimbra, Portugal.

${ }^{2}$ Ph.D. in Nursing. Professor, Escola de Enfermagem Anna Nery (EEAN), Universidade Federal do Rio de Janeiro (UFRJ). Rio de Janeiro, Rio de Janeiro, Brazil. E-mail: angelabreu@globo.com

${ }^{3}$ Ph.D. in Management. Professor, School of Nursing of Coimbra. Coimbra, Portugal. E-mail: parreira@esenfc.pt

${ }^{4}$ Ph.D. in Nursing. Professor, EEAN/UFRJ. Rio de Janeiro, Rio de Janeiro, Brazil. E-mail: mhnsouza@yahoo.com.br

${ }^{5}$ Ph.D. in Nursing. Professor, Escola Superior de Enfermagem de Coimbra. Coimbra, Portugal. E-mail: tbarroso@esenfc.pt
}

\begin{abstract}
The aim of this study was to analyze the profile of consumption of psychoactive substances in the past three months and their association with sociodemographic variables. A cross-sectional study was conducted with users of the Family Health Strategy in the perspective of the brief intervention, in the city of Rio de Janeiro, Brazil. The sample included 1,489 users of the service interviewed throughout a year. The consumption of substances was assessed through the questionnaire Alcohol, Smoking and Substance Involvement Screening Test. Statistical analysis was developed using the software SPSS. The highest prevalence rates in the past three months were found in the male subsample for use of tobacco (56.4\%), alcoholic drinks (75.8\%), cannabis (16.9\%), and cocaine/crack (10.1\%). Religion and educational level appear as an important protective factor against the use of drugs. A prevalence of consumption of psychoactive substances among the users of this area within the scope of work of nurses was evidenced.
\end{abstract}

DESCRIPTORS: Primary health care. Alcohol drinking. Tobacco. Street drugs. Public health nursing.

\section{PERFIL DO CONSUMO DE SUBSTÂNCIAS PSICOATIVAS E SUA RELAÇÃO COM AS CARACTERÍSTICAS SOCIODEMOGRÁFICAS: UMA CONTRIBUIÇÃO PARA INTERVENÇÃO BREVE NA ATENÇÃO PRIMÁRIA À SAÚDE, RIO DE JANEIRO, BRASIL}

RESUMO: Objetivou-se analisar o perfil de consumo de substâncias psicoativas nos últimos três meses e sua associação com as variáveis sociodemográficas. Trata-se de um estudo transversal realizado com clientes atendidos na Estratégia Saúde da Família, na perspectiva da Intervenção Breve. O estudo aconteceu na cidade do Rio de Janeiro, Brasil. A amostra incluiu 1489 usuários do serviço, entrevistados ao longo de um ano. O consumo das substâncias foi avaliado pelo questionário Alcohol, Smoking and Substance Involvement Screening Test. A análise estatística foi elaborada no software SPSS. As maiores prevalências nos últimos três meses foram detectadas na subamostra masculina para o uso do tabaco $(56,4 \%)$, bebidas alcoólicas $(75,8 \%)$, cannabis $(16,9 \%)$ e cocaína/crack $(10,1 \%)$. A religião e a escolaridade emergem como importante fator protetor para o uso das drogas. Evidenciou-se uma prevalência do consumo de substâncias psicoativas dentre os clientes atendidos nessa área, no âmbito da prática do enfermeiro.

DESCRITORES: Atenção primária à saúde. Consumo de bebidas alcoólicas. Tabaco. Drogas ilícitas. Enfermagem em saúde pública. 


\title{
PERFIL DEL CONSUMO DE SUSTANCIAS PSICOACTIVAS Y SU RELACIÓN CON LAS CARACTERÍSTICAS SOCIODEMOGRÁFICAS: UNA CONTRIBUCIÓN PARA INTERVENCIÓN BREVE EN LA ATENCIÓN PRIMARIA A LA SALUD, RIO DE JANEIRO, BRASIL
}

\begin{abstract}
RESUMEN: Se objetivó analizar el perfil de consumo de sustancias psicoactivas en los últimos tres meses y su asociación con las variables sociodemográficas. Se trata de un estudio transversal de los pacientes incluidos en la Estrategia Salud de la Familia en la perspectiva de la Intervención Breve. El estudio se llevó a cabo en la ciudad de Río de Janeiro, Brazil. La muestra estuvo constituida de 1498 usuarios del Servicio, entrevistados por el periodo de un año. El consumo de sustancias se evaluó mediante un cuestionario Alcohol, Smoking and Substance Involvement Screening Test. El análisis estadístico se realizó con el software SPSS. Las prevalencias en los últimos tres meses fue detectada en la submuestra masculina para el uso de tabaco (56,4\%), bebidas alcohólicas $(75,8 \%)$, cannabis (16,9\%) y cocaína/crack (10,1\%). La religión y la escolaridad emergen como importante factor para el uso de drogas. Se evidenció una prevalencia del consumo de sustancias psicoactivas, de la clientela atendida en esta área en el ámbito de la práctica del enfermero.
\end{abstract}

DESCRIPTORES: Atención primaria de salud. Consumo de bebidas alcohólicas. Tabaco. Drogas ilícitas. Enfermería en salud pública.

\section{INTRODUCTION}

The problems related to the use and abuse of psychoactive substances associated with the use of new prevalent abuse substances has become a serious public health problem nowadays..$^{1-3}$ The United Nations Office on Drugs and Crime (UNODC), together with the World Health Organization (WHO), in their report on drugs treatment and care, pointed out that 205 million people use illicit drugs worldwide; 25 million consist of addicted people, including the use of drugs in the group of the 20 major risk factors for health in the world and one of the 10 main factors in developing countries. ${ }^{1}$

In this sense, the main study of prevalence of psychoactive substances conducted in Brazil in 2005 by the Brazilian Center for Psychotropic Drug Information (CEBRID) confirmed the prevalence of use of licit and illicit drugs, evidencing that $74.6 \%$ of the users had made use of alcohol at least once in life, followed by $44 \%$ for tobacco use, and $22.8 \%$ for use of illicit drugs. On the occasion it was also evidenced that the mean age for starting consumption was 16 years for tobacco and 17 years for alcohol and illicit drugs. ${ }^{4}$

The rapid emergence of new substances combined with the use of alcohol, crack, and other drugs and their relationship to accidents or situations of violence evidence the increased severity of the injuries and the reduced potential years of life of the population, exposing people to risk behaviors. ${ }^{1}$ Accidents and violence represent the second cause of general mortality and the leading cause of death among people aged between 10 and 49 years. This profile persists in the historical series of the Mortality System of the Brazilian Ministry of Health in the past eight years. ${ }^{5}$

In general, drug users seek specialized services at an advanced stage of consumption. Therefore, it is possible to infer that the intervention at an early stage of the problem improves the prognosis, requiring the development of strategies of detection and brief interventions as a means of tracking in a population likely to use such substances. Thus, primary health care services consist in a privileged space for this initial tracking and follow-up. ${ }^{6-8}$

Therefore, the policy of the Ministry of Health for comprehensive care of users of alcohol and other drugs recommends that therapeutic and preventive actions for people who use these substances and their families be conducted in the community, establishing that care programs for this population provide comprehensive care in basic care units and non-specialized clinics through the Family Health Strategy (FHS), ${ }^{5-8}$ as through this comprehensive care health professionals have contact with a large number of people that should be approached in relation to the way they use alcohol and other drugs. It should be the preferred form of contact to users, the main gateway, and center of communication with the whole health care network. ${ }^{8}$

In this context, the use of concise, short-term therapeutic techniques has been an important element in the spectrum of care available to approach and treat users of alcohol and other drugs. ${ }^{6-9}$ One of these techniques is the brief intervention (BI), a technique intended to modify the behavior of users in relation to the most used psychoactive substance that causes them problems, helping them to understand that such use puts them at risk, serving as a motivation for them to reduce or quit the use of drugs. ${ }^{6-7,9}$

Particularly, within primary care, BI consists in offering a brief feedback and advice aiming at motivating users of low and moderate risk psychoactive substances to change their way of using, creating a bond between their current habits of use and the associated risks/ harms. ${ }^{7,9}$ 
Studies point out that triage, at primary care, may increase the probability of identification of individuals using substances in a consumption that, although non-addicted, is harmful or dangerous, enabling the professional to perform an intervention. Such detection, with the tracking, enables health professionals to have an opportunity to educate users on the risks of such substances. ${ }^{2,6-7,9-11}$ Thus, a number of common health problems may be minimized under the perspective of primary health care.

The relevance of the present study in the area of FHS is emphasized in this context, taking into account the scarce national literature on the theme. Given the above, this study aimed at analyzing the profile of consumption of psychoactive substances in the past three months and its association with the sociodemographic variables in users of the FHS in the perspective of the brief intervention.

\section{METHOD}

This was a quantitative, descriptive, cross-sectional study conducted with users of a family health clinic that operates in the FHS model, consisting of 12 teams, responsible for the primary health care of nearly 40,000 people, located in the Complexo do Alemão, in the northern region of the city of Rio de Janeiro, Brazil. Each family health team is responsible for approximately 3,000 people.

Data were collected in the family health clinic in six work teams containing scholarship students tutored by the Labor Education Program for Health (PET-Health).$^{10}$ The convenience sample consisted of 1,489 individuals aged over 18 years, both male and female, who went to the unit and were referred to the nursing service. The criterion of exclusion consisted in individuals that had no condition to answer the questionnaire due to mental disability.

Data collection occurred between July 2013 and July 2014, conducted by 12 nursing undergraduate scholarship students of the PET-Health program, previously trained to work as interviewers along with the nurses of these six teams, who had also been previously properly trained by the main researcher, tutor of the project, and responsible for the research. These students were distributed in the respective teams, and each one of them was present once or twice a week within the study period to collect data.

The instrument used in this study was the questionnaire Alcohol, Smoking and Substance Involvement Screening Test (ASSIST) version 3.1, ${ }^{9}$ with the sociodemographic profile. This triage ques- tionnaire was developed by the WHO to detect the consumption of alcohol, tobacco, and other drugs (cannabis, cocaine/crack, amphetamines, sedatives, hallucinogens, inhalants, and opiates). Its use is indicated in the area of primary health care.

The scores of the answers of the ASSIST range from zero to 33 points; the total score value was used for each psychoactive substance for the execution of statistical tests. However, the levels range from casual use, abuse, and addiction. The range from 0 to 3 is considered as casual use, scores from 4 to 26 indicate abuse, and 27 or more suggests addiction. It is important to mention that the scoring to assess the pattern of consumption of alcohol differs from the other substances. Alcohol presents a higher tolerance, with scores ranging from 0 to 10 as indicative of casual use; between 11 and 26 as indicative of abuse; and scores above 27 as indicative of addiction..$^{9,12}$ This instrument aims at identifying, in primary health care, the levels of risk for the substances, classifying individuals in low, moderate, and high risk consumption of the nine classes of mentioned psychoactive substances within the past three months and also throughout the life of each participant.

The sociodemographic characterization variables used included gender, age, educational level, religion, marital status, and family income. This study aimed at analyzing the profile of consumption of psychoactive substances in the past three months and its relationship to the sociodemographic variables. As the sample presents a high " $n$ " and based on the central limit theorem, parametric statistics were used. However, a correlation of Spearman was presented to assess association between the variables, as "educational level" is a variable of ordinal measurement level. Student's t-test and ANOVA were also used to assess differences of means for two or more groups using the software Statistical Package for the Social Sciences (SPSS) version 22.0, establishing a level of statistical significance for $\mathrm{p}<0.05$.

The ethical procedures of the study were represented by the approval by the Research Ethics Committee of the Municipal Secretariat of Health and Civil Defense of Rio de Janeiro under protocol 132/09 and through the signature of a free and informed consent form by the individuals who agreed to participate in the study.

\section{RESULTS}

In relation to the sociodemographic profile in general, the present study showed that $78.1 \%$ of the 
studied population consisted of female individuals, and their age ranged between 18 and 85 years, with a mean of 39 years and standard deviation of 15.3. Regarding their marital status, $58.8 \%$ of them were married, whereas $23.9 \%$ were single. As for their educational level, $34.0 \%$ of the individuals had not completed primary school, $16.4 \%$ concluded primary school, $22.6 \%$ completed secondary school, $15.9 \%$ had not completed secondary school, and $2.7 \%$ had a university degree. Of the $77.8 \%$ who reported to practice a religion, $47.5 \%$ were catholic and $48.3 \%$ were evangelical. Regarding family income, a prevalence of $55.0 \%$ was found between one and two minimum wages, followed by $14.5 \%$ with income below a minimum wage, and $13.9 \%$ with income between two and three minimum wages.

Analysis of Table 1, regarding the relationship between the sociodemographic variables and the risk of consumption of psychoactive substances in the past three months shows that, in a nonspecific manner, the risk of consumption of substances is associated.

Age is correlated in a negative manner with the risk of consumption of alcoholic drinks ( $\mathrm{r}=-.08$; $\mathrm{p}<.01)$, cannabis $(\mathrm{r}=-.10 ; \mathrm{p}<.01)$, and inhalants $(\mathrm{r}=-$ $.06 ; \mathrm{p}<.05)$, i.e., increased ages reduce the risk in these three consumptions.

Educational level is negatively related to the use of tobacco $(\mathrm{r}=-.13 ; \mathrm{p}<.05)$, alcoholic drinks $(\mathrm{r}=-.061 ; \mathrm{p}<.05)$, and cocaine $(\mathrm{r}=-.56 ; \mathrm{p}<.05)$; such relations are significant. Thus, the higher the educational level, the lower the consumption of these substances.

Income is negatively correlated with consumption of tobacco $(\mathrm{r}=-.10 ; \mathrm{p}<.01)$, i.e., the higher the income, the lower the consumption of tobacco; such relation is statistically significant.

Table 1 - Correlations between the sociodemographic variables and the risk of consumption of psychoactive substances in the population assisted by the family health strategy, Rio de Janeiro, Brazil. 2013-2014. $(n=1,489)$

\begin{tabular}{|c|c|c|c|c|c|c|c|c|c|c|c|c|}
\hline & 1 & 2 & 3 & 4 & 5 & 6 & 7 & 8 & 9 & 10 & 11 & 12 \\
\hline 1 - Age & 1 & $-.27 \dagger$ & $.08 \dagger$ & .05 & $-.08 \dagger$ & $-.10 \dagger$ & -.04 & -.05 & $-.06^{*}$ & .04 & -.04 & .00 \\
\hline 2 - Educational level & & 1 & $.22 \dagger$ & $-.13 \dagger$ & $-.06^{*}$ & -.00 & $-.06^{*}$ & .00 & .00 & .02 & -.05 & .02 \\
\hline 3 - Income & & & 1 & $-.10 \dagger$ & -.01 & -.03 & -.03 & -.02 & -.02 & -.01 & -.03 & -.02 \\
\hline 4 - Tobacco & & & & 1 & $.35 \dagger$ & $21 \dagger$ & $.13 \dagger$ & $.10 \dagger$ & $.07^{*}$ & .04 & $.08 \dagger$ & -.02 \\
\hline 5 - Alcohol & & & & & 1 & $.16 \dagger$ & $.13 \dagger$ & $.11 \dagger$ & $.08 \dagger$ & $.06^{*}$ & $.08 \dagger$ & -.03 \\
\hline 6 - Cannabis & & & & & & 1 & $.40 \dagger$ & $.33 \dagger$ & $.23 \dagger$ & .04 & $.28 \dagger$ & $.05^{*}$ \\
\hline 7 - Cocaine & & & & & & & 1 & $.25 \dagger$ & $.29 \dagger$ & $.07 \dagger$ & $.36 \dagger$ & $.07 \dagger$ \\
\hline 8 -Stimulants/ amphetamines & & & & & & & & 1 & $.10 \dagger$ & $.26 \dagger$ & $.52 \dagger$ & $.11 \dagger$ \\
\hline 9 - Inhalants & & & & & & & & & 1 & $.20 \dagger$ & $.20 \dagger$ & -.01 \\
\hline 10 - Hypnotics & & & & & & & & & & 1 & $.16 \dagger$ & .05 \\
\hline 11 - Hallucinogens & & & & & & & & & & & 1 & $.22 \dagger$ \\
\hline 12 - Opiates & & & & & & & & & & & & \\
\hline
\end{tabular}

* Significant correlation for a level of significance $\mathrm{p}<.05$; † Significant correlation for a level of significance $\mathrm{p}<0.01$.

Student's t-test was used to assess the differences in the risk of consumption of psychoactive substances in the past three months according to gender, religion, and marital status. As shown on Table 2, there were significant differences in the risk of consumption of tobacco $\left(\mathrm{M}_{\text {(Male) }}=4.60 \mathrm{M}_{(\mathrm{Fem})}=3.45\right.$; $\mathrm{p}=.033)$, alcohol $\left(\mathrm{M}_{(\mathrm{Male})}=4.90 ; \mathrm{M}_{(\mathrm{Fem})}=2.88 ; \mathrm{p}=.000\right)$, cannabis $\left(\mathrm{M}_{(\text {Male })}=., 65 ; \mathrm{M}_{(\mathrm{Fem})}=.17 ; \mathrm{p}=.036\right)$ and cocaine $\left(\mathrm{M}_{(\text {Male })}=.47 ; \mathrm{M}_{(\mathrm{Fem})}=.11 ; \mathrm{p}=.054\right)$; the male gender presented higher mean scores. However, the highest levels of risk of consumption of hypnotics were observed in the female gender $\left(\mathrm{M}_{\text {(Male) }}=.11\right.$; $\left.\mathrm{M}_{(\mathrm{Fem})}=.45 ; \mathrm{p}=.002\right)$.
Regarding the variable religion, lower scores of risk of consumption of tobacco, alcohol, cannabis, and cocaine were observed for those who reported to have a religion.

Considering marital status, higher levels of risk of consumption of tobacco and alcohol were observed for separated individuals; the differences among the different groups were significant. In relation to the use of hypnotics a higher mean score of consumption was observed for widowed individuals, with differences between the marital statuses $\left(\mathrm{M}_{\text {(Married) }}=.34 ; \mathrm{M}_{\text {(Single) }}=.28 ; \mathrm{M}_{\text {(Separated) }}=.43\right.$; $\mathrm{M}_{\text {(Widowed) }}=1.19 ; \mathrm{p}=.016$ ). 
Table 2 - Difference of mean values in the scores of risk of consumption of psychoactive substances per gender, religion, and marital status in a sample receiving care in the FHS, Rio de Janeiro, Brazil. 2013-2014. $(n=1,489)$

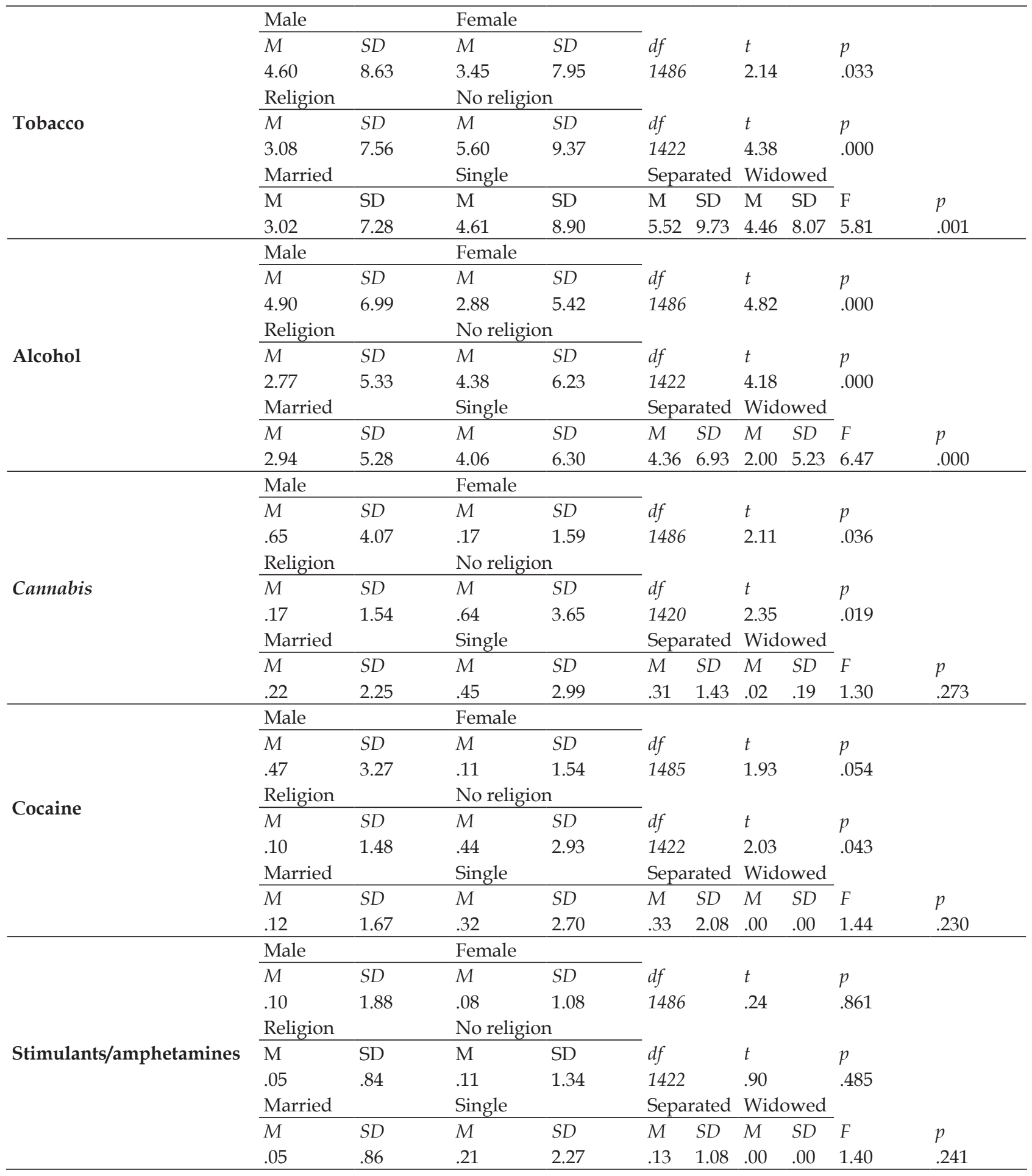




\begin{tabular}{|c|c|c|c|c|c|c|c|c|c|c|}
\hline & $\mathrm{Mal}$ & & Fem & & & & & & & \\
\hline & $\bar{M}$ & $S D$ & $M$ & $S D$ & $d f$ & & $t$ & & $p$ & \\
\hline & .21 & 2.64 & .04 & .33 & 1480 & & 1.88 & & .269 & \\
\hline & Reli & & No & & & & & & & \\
\hline Inhalants & $\bar{M}$ & $S D$ & $M$ & $S D$ & $d f$ & & $t$ & & $p$ & \\
\hline & .02 & .57 & .17 & 2.2 & 1416 & & 1.18 & & .238 & \\
\hline & Mar & & Sing & & Sepa & rated & Wid & owed & & \\
\hline & $\bar{M}$ & $S D$ & $M$ & $S D$ & & $S D$ & & $S D$ & $F$ & $p$ \\
\hline & .06 & 1.28 & .20 & 2.13 & .00 & .00 & .00 & .00 & 1.13 & .333 \\
\hline & $\mathrm{Mal}$ & & Fem & & & & & & & \\
\hline & $\bar{M}$ & $S D$ & $M$ & $S D$ & $d f$ & & $t$ & & $p$ & \\
\hline & .11 & 1.31 & .45 & 2.85 & 1484 & & -3.10 & & .002 & \\
\hline & Reli & & No & & & & & & & \\
\hline Hypnotics & $\bar{M}$ & $S D$ & $M$ & $S D$ & $d f$ & & $t$ & & $p$ & \\
\hline & .34 & 2.47 & .26 & 1.93 & 1420 & & -.61 & & .545 & \\
\hline & Mar & & Sing & & Sepa & rated & Wid & owed & & \\
\hline & $M$ & $S D$ & $M$ & $S D$ & $M$ & $S D$ & $M$ & $S D$ & $F$ & $p$ \\
\hline & .34 & 2.51 & .28 & 2.13 & .43 & 2.57 & 1.19 & 4.70 & 3.46 & .016 \\
\hline & $\mathrm{Mal}$ & & Fem & & & & & & & \\
\hline & $\bar{M}$ & $S D$ & $M$ & $S D$ & $d f$ & & $t$ & & $p$ & \\
\hline & .10 & .16 & .01 & .44 & 1484 & & -2.12 & & .733 & \\
\hline & Reli & & No & & & & & & & \\
\hline Hallucinogens & $\bar{M}$ & $S D$ & $M$ & $S D$ & $d f$ & & $t$ & & $p$ & \\
\hline & .01 & 1.17 & .01 & .44 & 1420 & & 1.12 & & .262 & \\
\hline & Mar & & Sing & & Sepa & rated & Wid & wed & & \\
\hline & $\bar{M}$ & $S D$ & $M$ & $S D$ & $M$ & $S D$ & $M$ & $S D$ & $F$ & $p$ \\
\hline & .00 & .00 & .06 & .84 & .00 & .00 & .00 & .00 & 1.79 & .148 \\
\hline & $\mathrm{Mal}$ & & Fem & & & & & & & \\
\hline & $\bar{M}$ & $S D$ & $M$ & $S D$ & $d f$ & & $t$ & & $p$ & \\
\hline & .01 & .00 & .06 & .10 & 1483 & & 2.12 & & .411 & \\
\hline & Reli & & No & & & & & & & \\
\hline Opiates & $M$ & $S D$ & $M$ & $S D$ & $d f$ & & $t$ & & $p$ & \\
\hline & .04 & .83 & .06 & .13 & 1420 & & .29 & & .809 & \\
\hline & Mar & & Sing & & Sep & rated & Wid & wed & & \\
\hline & $\bar{M}$ & $S D$ & $M$ & $S D$ & $M$ & $S D$ & $M$ & $S D$ & $F$ & $p$ \\
\hline & .29 & .54 & .06 & 1.01 & .00 & .00 & .26 & 2.20 & 2.25 & .081 \\
\hline
\end{tabular}

$\mathrm{M}=$ mean; $\mathrm{SD}=$ standard deviation; $\mathrm{df}=$ degrees of freedom; $\mathrm{F}=$ statistics; $\mathrm{p}=$ statistical significance.

Table 3 shows, under the categories, the levels of risk for those who used psychoactive substances in the past three months, based on the score obtained in the ASSIST. Then, the low, moderate, and high risk percentage values are introduced, respectively, for all the substances. For alcohol, moderate risk $8.8 \%$ (131) and high risk $1.2 \%$ (18) were emphasized. For tobacco, $16.6 \%$ (247) of moderate risk and 3.5\% (52) of high risk were pointed out. For the risk of consumption of cannabis, $1.5 \%$ (22) of moderate risk and $0.3 \%$ (4) of high risk were observed. The risk of consumption of hypnotics/sedatives reaches a percentage of $2.1 \%$ (31) for moderate risk and $0.3 \%$ (4) for high risk. Moderate risk of consumption of cocaine reaches the expression of $0.8 \%$ (12) with high risk of $0.3 \%$ (4). Stimulants showed moderate risk of
$0.5 \%(8)$ and high risk of $0.1 \%$ (1). Opiates showed only $0.3 \%$ (5) of moderate risk. Inhalants presented moderate risk of $0.3 \%$ (5) and high risk of $0.1 \%$ (2). Hallucinogens presented $0.1 \%$ (1) for moderate risk.

Table 3 - Distribution by classification of risk of each substance among the users of the family health strategy. Rio de Janeiro, Brazil. 2013-2014 $(n=1,489)$

\begin{tabular}{lrr}
\hline Substances & n & \% \\
\hline Alcohol & & \\
Low risk & 1340 & 90.0 \\
Moderate risk & 131 & 8.8 \\
High risk & 18 & 1.2 \\
Tobacco & &
\end{tabular}




\begin{tabular}{|c|c|c|}
\hline Low risk & 1190 & 79.9 \\
\hline Moderate risk & 247 & 16.6 \\
\hline High risk & 52 & 3.5 \\
\hline \multicolumn{3}{|l|}{ Cannabis } \\
\hline Low risk & 1461 & 98.3 \\
\hline Moderate risk & 22 & 1.5 \\
\hline High risk & 4 & 0.3 \\
\hline \multicolumn{3}{|c|}{ Hypnotics/sedatives } \\
\hline Low risk & 1452 & 97.6 \\
\hline Moderate risk & 31 & 2.1 \\
\hline High risk & 4 & 0.3 \\
\hline \multicolumn{3}{|l|}{ Cocaine/crack } \\
\hline Low risk & 1472 & 98.9 \\
\hline Moderate risk & 12 & 0.8 \\
\hline High risk & 4 & 0.3 \\
\hline \multicolumn{3}{|c|}{ Stimulants/amphetamines } \\
\hline Low risk & 1480 & 99.4 \\
\hline Moderate risk & 8 & 0.5 \\
\hline High risk & 1 & 0.1 \\
\hline \multicolumn{3}{|l|}{ Opiates } \\
\hline Low risk & 1481 & 99.7 \\
\hline Moderate risk & 5 & 0.3 \\
\hline High risk & - & - \\
\hline \multicolumn{3}{|l|}{ Inhalants } \\
\hline Low risk & 1476 & 99.5 \\
\hline Moderate risk & 5 & 0.3 \\
\hline High risk & 2 & 0.1 \\
\hline \multicolumn{3}{|l|}{ Hallucinogens } \\
\hline Low risk & 1486 & 99.9 \\
\hline Moderate risk & 1 & 0.1 \\
\hline High risk & - & - \\
\hline
\end{tabular}

\section{DISCUSSION}

A study was conducted in a population of primary health care users within the scope of the family health strategy in the city of Rio de Janeiro aiming at analyzing the profile of consumption of psychoactive substances in the past three months and its association with the sociodemographic variables in the perspective of the brief intervention. Given these results, in the past three months, it was observed that in our sample, in a general manner, the sociodemographic profile was predominantly female, with a mean age of 39 years, married, with low educational level, and low income. Also, most of them reported to have a religion. These data are similar to population-based studies ${ }^{13}$ and other Brazilian studies conducted in primary health care services. ${ }^{2,11,14}$

Regarding the age group, higher levels of risk were observed in younger individuals in relation to the consumption of alcohol, cannabis and inhalants. On the other side, higher risk of tobacco consumption was observed in older individuals. The latter may be explained by the anti-smoking campaign in
Brazil that has been in force for over two decades, and possibly this generation was not covered by this campaign when they were young. However, in relation to higher risks for younger individuals, we may point out higher investments and interventions in health education in schools as recommended by the Health at School Program of the Ministry of Health, particularly providing information and lectures at schools, clubs, and associations in areas assisted by the FHS on psychoactive substances. In this sense, authors point out that these interventions may reflect on important changes in the current and future development of these young individuals. ${ }^{15}$

Moreover, the higher the educational level and income, the lower the consumption of these substances, evidencing education as a protective factor. It is possible to infer that these characteristics are related to the formation and education in the schools, that is, the higher the level of information, the better the understanding of these people on the sense of promotion of health and quality of life. These data corroborate the findings of similar studies., ${ }^{2,14-15}$

In relation to the mean scores of risk of consumption of psychoactive substances in the past three months, the present study pointed out higher scores related to the consumption of tobacco, alcohol, cannabis, and cocaine for men, emphasizing a higher risk of consumption for individuals who are separated, single, widowed, and have no religion. Epidemiologic data and data from other studies corroborate these findings. ${ }^{2,4,11,16} \mathrm{It}$ is possible to observe and possibly explain the higher risk of consumption by those men for these substances due to the social determinants and the context in which they are inserted, emphasizing social vulnerabilities, such as low educational level, low income, poverty, and even the proximity with violence, as pointed out in international reports. ${ }^{17}$

On the other hand, a higher risk of consumption as observed in relation to the use of hypnotics for women, with a higher mean value among widowed individuals, corroborating the results found for men regarding the marital status and pointing out a higher risk of use of substances for single, separated, and widowed men, thus evidencing a higher protection for married men, that is, those who have a family. It is possible to observe that the proportion in which the individual establishes themselves, that is, without a partner and/or family, the opportunity to use psychoactive substances is increased, reinforcing the family as a protective factor in relation to the use of these substances. These data corroborate other studies conducted in primary care. ${ }^{11,14,16}$ 
Moreover, the study emphasizes the protective role of the variable religion for the risk of consumption of these substances, appearing in the study as a protective factor to the users. Authors have been pointing out religiosity as a protective factor against the consumption of drugs, ${ }^{18-20}$ reinforcing that religiosity remains a protective factor against the use of psychoactive substances, both licit and illicit. In this context, it is possible to infer that religion may represent a strength in the sense of helping the professional of the Family Health team to develop preventive actions for the community in partnership with the churches in the covered area in the planning of educational actions for health. ${ }^{21}$

Finally, according to the level of risk of consumption of psychoactive substances in the past three months, users were classified into three categories. Thus, it was observed that most of the population was classified in the low risk consumption, as expected. Therefore, for the population in this group, following the brief intervention model, ${ }^{6,9,12}$ in the feedback, after answering the questionnaire about the use of substances, the nurse and/ or nursing undergraduates of the scholarship program informed about the results, congratulated them, and provided information relating to health in general. Regarding the individuals whose consumption was classified in the moderate risk group, the brief intervention model $^{6,9}$ was conducted with guidelines for health in relation to the used substance, providing an information leaflet for the user to take home, and finally those patients classified in the high risk group were also instructed in the same way and then referred to assessment and treatment in specialized services.

In this sense, national ${ }^{2,11,14,16}$ and internation$\mathrm{al}^{20,22-23}$ authors have pointed out the efficacy of this model of brief intervention performed by professionals working in primary health care. Therefore, the present study emphasizes the importance of the qualification of the health professionals that develop their activities in primary health care in the FHS in order to provide a better service to people with problems related to alcohol and other drugs welcomed at the health system gateway.

Due to their opportunities of professional performance in a number of scenarios, nurses particularly have a prominent position, as they may apply the BIs to create an opportunity of preventive intervention for diseases caused by alcohol and other drugs. Nurses working in the FHS may particularly incorporate in the nursing visits a brief moment intended for the identification of patients with problems related to the use of these substances. In visits of patients with hypertension, diabetes, leprosy, tuberculosis, or pregnant women in prenatal visits, and also in health education for groups of adolescents, nurses may help people that may benefit by reducing or quitting the use of such substances. ${ }^{11,14-15,20,24}$

However, it is important to mention that this study presents some limitations, such as the possibility of occurrence of memory biases as it was conducted in one single area of the city of Rio de Janeiro covered by the FHS. Finally, this study highlights the importance of developing other studies on the theme aimed at knowing the magnitude of the use of psychoactive substances in primary health care that may support the strengthening of public health policies in this area.

\section{CONCLUSION}

In view of the presented results, the analysis of the profile of consumption of psychoactive substances in the past three months of these users evidenced the scenario of this population treated in the family health strategy, where it is possible to observe the presence of problems related to consumption of alcohol and other drugs. Therefore, it indicates opportunities for professionals of the FHS and particularly nurses to perform activities related to the prevention of diseases and promotion of health within the current national policy of basic care in this area. In a general manner, the risks of consumption are interdependent, regardless of being licit or illicit drugs, and further investments in information, especially for young people, must be made.

The use of an instrument (in this case the questionnaire ASSIST) to measure the classification of risk of each substance (low risk, moderate risk, and high risk) points out the fundamental reasons to detect the path to be followed in the systematization of the nurse's visit in this area for a brief intervention, as well as the problems related to the consumption of substances and how to include the test for detection of substances in the daily practice.

Finally, this study points out that the nurse working in the FHS is in an important position in the identification of patients that make use of psychoactive substances, as there is a reorientation of the model in primary care in this context, as recommended by the current national and international public health policies.

\section{REFERENCES}

1. World Health Organization (WHO). Global status report on alcohol and health 2014. Genebra $(\mathrm{CH})$ : WHO; 2014. 
2. Jomar RT, Abreu AMM, Griep RH. Caracterização do consumo de álcool de uma população adscrita à Estratégia Saúde da Família. Esc Anna Nery 2014; 18(1):96-100

3. United Nations Office on Drugs and Crime. World drug report United Nations. New York (US): ONU; 2013.

4. Queiroz NR, Portela LF, Abreu AMM. Associação entre o consumo de bebidas alcoólicas e tabaco e a religiosidade. Acta Paul Enferm. 2015; 28(6):546-52.

5. Ministério da Saúde (BR). Política do Ministério da Saúde para a atenção integral a usuários de álcool e outras drogas. Brasília (DF); 2004 [cited 2015 Sep 9]. Available from: http://bvsms.saude.gov.br/bvs/ publicacoes/pns_alcool_drogas.pdf

6. Ministério da saúde (BR). Plano emergencial de ampliação do acesso ao tratamento e prevenção em álcool e outras drogas no Sistema Único de Saúde. Portaria GM n ${ }^{\circ}$ 1.190, de 4 de junho de 2009. Brasília (DF): MS; 2009.

7. Ronzani TM, Souza ICW. Álcool e drogas na atenção primária: avaliando estratégias de capacitação. Psicol Estud. 2012; (17):237-46.

8. Ministério da Saúde (BR). Secretaria de Atenção à Saúde. Departamento de Atenção Básica. Política Nacional de Atenção Básica. Brasília (DF): MS; 2012.

9. Humeniuk R, Henry-Edwards S, Ali R, Poznyak V, Monteiro MG. The Alcohol, Smoking and Substance Involvement Screening Test (ASSIST): manual for use in primary care. Genebra $(\mathrm{CH})$ : World Health Organization; 2010.

10. Ministério da Saúde (BR). Portaria interministerial $n^{\circ} 421$, de 3 de março de 2010. Institui o Programa de Educação pelo Trabalho para a Saúde (PET Saúde) e dá outras providencias. Brasilia (DF): MS; 2010.

11. Jomar RT, Abreu AMM, Griep RH. Padrões de consumo de álcool e fatores associados entre adultos usuários de serviço de atenção básica do Rio de Janeiro, RJ, Brasil. Ciênc Saúde Coletiva. 2014; 19(1):27-37

12. Henrique IF, De Micheli D, Lacerda RB, Lacerda LA, Formigoni ML. Validation of version alcohol, smoking, and substance involvment screening test. Rev Assoc Med Bras. 2004; 50(2):199-206.

13. Ministério da Saúde (BR). Secretaria de Vigilância em Saúde. Departamento de Vigilância de Doenças e Agravos não Transmissíveis e Promoção da Saúde. Brasília (DF): MS; 2015.

14. Jomar RT, Abreu AMM. Intervenções breves para uso problemático de álcool: potencial de aplicação na prática do enfermeiro. Rev Enferm UERJ. 2012 20(3):391-95.
15. Barroso TMMDA, Mendes AMOC, Barbosa AJF. Programa de prevenção do uso/abuso de álcool para adolescentes em contexto escolar: parar para pensar. Esc Anna Nery. 2013; 17(3):466-73.

16. Souza J, Luis MAV, Corradi-Webster CM. Brief interventions and tools for nursing care: descriptive and exploratory study. Online Braz J Nurs [Internet]. 2013 [cited 2016 Apr 22]; 12(1):21-32. Available from: http://www.objnursing.uff.br/index.php/nursing/ article/view/3504/html

17. Reichenheim ME, Souza ER, Moraes CL, Mello Jorge MHP, Silva CMFP, Minayo MCS. Violência e lesões no Brasil: efeitos, avanços alcançados e desafios futuros. The Lancet 2011; 6736(11)75-89.

18. Gomes FC, Andrade AG, Izbicki R, Almeida MA, Oliveira LG. A religião como um fator de proteção contra o uso de drogas entre os universitários brasileiros: uma pesquisa nacional. Rev Bras Psiquiatr. 2013 35(1):29-37.

19. Edlund MJ, Harris KM, Koenig HG, Han X, Sullivan G, Mattox R, et al. Religiosity and decreased risk of substance use disorders: is the effect médiated by social support or mental health status. Soc Psychiatry Epidemiol. 2010; 45(8):827-36.

20. Le KB, Johnson JA, Seale JP, Woodall H, Clark DC, Parish DC, et al. Primary care residents lack comfort and experience with alcohol screening and brief intervention: A multi-site survey. J Gen Intern Med. 2015; 30(1):161-8.

21. Reis LM, Hungaro AA, Oliveira MLF. Public policies for confronting the use of illicit drugs: social perception in a community. Texto Contexto Enferm [Internet]. 2014 Out-Dez [cited 2016 Apr 22]; 23(4):1050-8. Available from: http://www. scielo.br/scielo.php?script=sci_arttext\&pid=S010407072014000401050\&lng=en\&nrm=iso\&tlng=en

22. Schonfeld L, Hazlett RW, Hedgecock DK. Screening, brief intervention, and referral to treatment for older adults with substance misuse. Am J Public Health. 2015 Jan; 105(1):205-11.

23. Mdege ND, Watson J. Predictors of study setting (primary care vs. hospital setting) among studies of the effectiveness of brief interventions among heavy alcohol users: A systematic review. Drug Alcohol Rev. 2013 Jul; 32(4):368-80.

24. Gonçalves AMS Ferreira PS, Abreu AMM, Pillon SC, Jezus SV. Estratégias de rastreamento e intervenções breves como possibilidades para a prática preventiva do enfermeiro. Rev Eletr Enferm [Internet]. 2011 [cited 2016 Apr 22]; 13(2):355-60. Available from: https:/ / www.fen.ufg.br/fen_revista/v13/n2/v13n2a23.htm 